\title{
Land and Water Systems: Looking to the future and a more resilient and sustainable society and environment
}

Elisabetta Gotor; Swamikannu Nedumaran; Nicola Cenacchi; Nhuong Tran; Shahnila Dunston; Ahmad Dermawan; Harold Valera; David Wiberg; Kindie Tesfaye; Kai Mausch; and Simon Langan

\section{CGIAR Foresight}

Strategic foresight and modeling to support food systems decision making. 


\title{
Land and Water Systems: Looking to the future and a more resilient and sustainable society and environment
}

\author{
Elisabetta Gotor ${ }^{1}$; Swamikannu Nedumaran²; Nicola Cenacchi ${ }^{3}$; Nhuong Tran ${ }^{4}$; Shahnila Dunston ${ }^{3}$; \\ Ahmad Dermawan ${ }^{5}$; Harold Valera ${ }^{6}$; David Wiberg ${ }^{7}$; Kindie Tesfaye ${ }^{8}$; Kai Mausch ${ }^{9}$; and Simon Langan ${ }^{7}$
}

December $21^{\text {st }}, 2021$

1: Bioversity International

2: ICRISAT-IN

3: IFPRI

4: WorldFish

5: CIFOR

6: IRRI

7: IWMI

8: CIMMYT

9: World Agroforestry (ICRAF)

This document is one of a collection of three working papers and a synthesis brief edited by Steven Prager and Keith Wiebe, and prepared as part of foresight-related research supported by the CGIAR Research Program on Policies, Institutions, and Markets. These working papers are intended to provide a forward-looking perspective on key issues to support discussion on food, land, and water systems transformation. We are grateful to members of a steering committee (Stephan Weise, Frank Place, Marianne Bänziger, Vincent Gitz, Oscar Ortiz, Michael Phillips, Tom Randolph, May-Guri Saethre, and Mark Smith) for their guidance, as well as to several anonymous reviewers for their comments on an earlier draft.

These working papers and the synthesis brief will be made available at http://foresight.cgiar.org. 


\section{Abstract}

Food, land, and water systems are facing unprecedented change. The world's population is projected to grow to approximately 10 billion people by 2050, while aging and declining in some regions. Global average incomes are expected to keep increasing at a slow but steady pace. With increasing incomes and the ability of consumers to purchase more and better food in combination with population growth, food demand is projected to grow substantially over the next three decades. Meanwhile, demographic changes and economic development also drive urbanization, migration, and structural transformation of rural communities. At the same time changes to precipitation and temperature as well as the occurrence of extreme events driven by climate change are becoming more prevalent and impacting society and the environment. Currently, humanity is approaching or exceeding planetary boundaries in some areas, with over-use of limited productive natural resources such as water and phosphate, net emissions of greenhouse gases, and decreases in biodiversity

Much is published about food and agriculture and the supporting/underpinning land and water systems, but no single source focuses regularly and systematically on the future of agriculture and food systems, particularly on the challenges and opportunities faced by developing countries. This working paper is part of an effort by the CGIAR foresight team to help fill that gap. The effort recognizes that there is much to learn from past experience, and there are clearly many urgent and immediate challenges, but given the pace and complexity of change we are currently experiencing, there is also an increasing need to look carefully into the future of food, land, and water systems to inform decision making today. 


\section{Table of Contents}

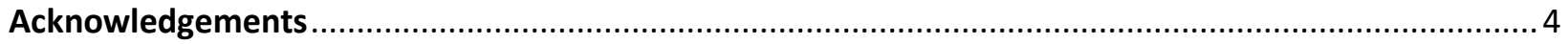

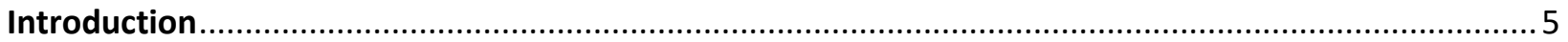

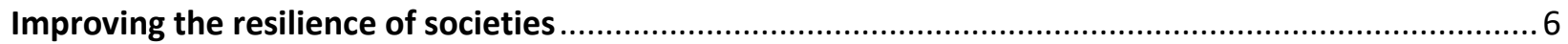

Climate adaptation and mitigation in agrarian based societies ..................................................... 7

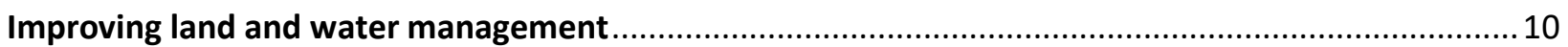

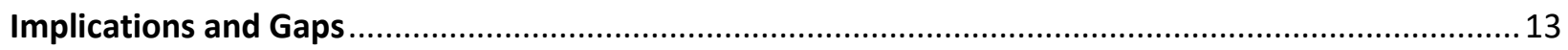

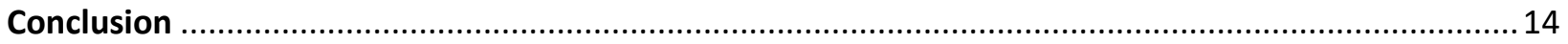

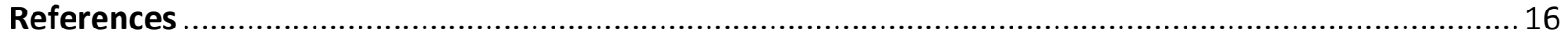

\section{Acknowledgements}

This paper was prepared with support from the CGIAR Research Program on Policies, Institutions, and Markets (PIM). Additional support from the CGIAR Research Programs on Climate Change, Agriculture and Food Security (CCAFS) and Water, Land and Ecosystems (WLE) is also highly appreciated by the authors. 


\section{Introduction}

Food, land, and water systems are being managed and utilized unsustainably; these unsustainable practices are occurring amidst a changing and developing society as well as interacting with a changing climate. As we look to the future to identify likely challenges and probable options for improving resource utilization and management, there are a range of unknowns and uncertainties. Research can help improve the evidence for informed decision-making. In order to attain this vision of environmental and socioeconomic resilience, we must leverage analytical views of the future to generate the evidence base needed to support better decision making from scientists, educators, investors or policy advisors. This report summarizes the characteristics of three major challenges, likely trajectories into the future, possible solution options, and uncertainties associated with trying to understand and manage them in sustainable ways. These three challenges can be synthesized into key messages as follows:

a. Under expected pathways of socio-economic development and climate change, there are significant opportunities for improving the resilience of societies through integrated economic, governance as well as technical solutions as related to land and water systems and their management. Resilient agriculture and food systems have the potential to service as the foundation for resilience across the broader economy.

b. Increasingly, climate change will contribute to and exacerbate existing challenges associated with the impacts of extreme events (floods, droughts, heatwaves, storms), and will affect, in a disproportionate way, those who are already vulnerable in agrarian based societies. These impacts are expected to worsen in the near- to mid- term (2030 - 2050) unless appropriate adaptation measures are taken at required spatial and temporal scales.

c. Due to historical and current unsustainable use, increasing overutilization, poor management, and the impacts of changing climate, land and water resources will be under heavy pressure to support food systems and provide ecosystem services in the near (2030) and mid (2050) terms. Therefore, there is a need to identify and implement opportunities (2030 and beyond to 2050) to sustainably intensify and improving land and water management through approaches that integrate agricultural, land and water management systems, - especially in developing countries and regions of the world.

Globally, the importance of these issues have been recognized and policy frameworks established, namely: the Agenda 2030 for Sustainable Development (https://sdgs.un.org/2030agenda); The Sendai Framework for Disaster Risk Reduction (https://www.undrr.org/publication/sendai-framework-disasterrisk-reduction-2015-2030 ); The Paris Agreement (https://unfccc.int/process-and-meetings/the-parisagreement/the-paris-agreement ) as well as developing frameworks, such as the Convention of Biological Diversity (https://www.cbd.int/convention/). Taking these policy directives and their adoption provides an enabling framework to tackle the challenges described in the three points above. This requires an understanding of system shocks, step changes, and specific adaptations at local, regional and global levels across different agroecological zones (nested scales). There is also a need to better understand system dynamics at a range of geographical and timescales in the context of sustainable development and adaptation. 
Here we place a specific emphasis on developing regions of the world in which individual country economies and regions are underpinned by agriculture, fisheries and aquaculture production, much of which is dominated by smallholders who often have to operate under constrained conditions. Many of the countries and regions we focus on are characterized by historical under-investment in fundamentals (e.g. in education, infrastructures, institutions), changeable governance, and associated low institutional and often individual technical capacity.

Below we summarize the status of the forward-looking evidence around the three key issues highlighted above.

\section{Improving the resilience of societies}

To improve resilience, we need to understand the different socioeconomic and biophysical drivers that affect land, water and food systems directly or indirectly. Many societal changes in developing regions are driven by some key factors, primarily: population growth (a dominant signal across much of Africa and Asia), economic growth (Asia), and migration both from rural to urban centers as well as migration between countries and continents ${ }^{1}$. Superimposed on this are the impacts of climate change - shortterm fluctuations and increases in intra- and inter- seasonal occurrences of extremes (floods, droughts, and storms leading to landslides as well as heatwaves) as well as and long-term changes such as increasing temperatures and more variable precipitation patterns.

Planning for changes in temperature and precipitation patterns (e.g. Amarnath et. al., 2019, 2021; Wada et. al., 2014) will both reduce vulnerability and improve resilience through methods such as early warning and innovative insurance mechanisms, improving integrated management and water productivity across sectors to ensure better productivity, enhancing ecosystem services, ensuring access to water and sanitation, and improving monitoring and access to information.

While increasing production and reducing hunger are long-standing concerns, in recent years agricultural models have been linked to health models to explore how changes in drivers such as population, income, demand for resource-intensive commodities can affect health and environmental outcomes. Continued economic development and income growth will be a major driving factor in a broader transformation of the food system, leading to increased demand for animal-sourced foods, fruits and vegetables, and processed foods, with a range of health and environmental outcomes. Several recent studies (Springmann, Clark, et al., 2018; Springmann, Sacks, et al., 2018; Springmann, Wiebe, et al., 2018; Willett et al., 2019) argue that changes in diet will be needed to avoid unsustainable increases in the use of cropland, water and fertilizer. Such changes face significant challenges, however. Hirvonen et al., (2020) estimate that the cost of the EAT-Lancet reference diet exceeds household per capita income for at least 1.58 billion people, which raises questions about equity and the social sustainability of such diets. The cost of the EAT-Lancet diet is assumed to remain as it currently is compared to the business as usual. However, this diet could potentially become much less expensive depending on changes in supply, value chains and taxation on unhealthy foods (Mytton, Clarke and Rayner, 2010; Springmann, Clark, et al., 2018).

\footnotetext{
${ }^{1}$ Other important societal-level changes are driven by advances in communication technology, changes in financial systems, changes in dietary preferences, as well as broader changes in philosophical and religious preferences.
} 
Building resilience requires understanding the link between ecosystem functions and services. In the past society focused more on provisioning services at the expense of regulating cultural and supporting services. In the future, there is a need for optimization across the nexus between socio-cultural, food systems and land and water systems, which requires understanding the trade-offs involved (Karki et al., 2018; Panyadee et al., 2018; Rahman et al., 2011; Sharma et al., 2018). Building resilience also requires improving productivity so that we can produce enough food to adequately feed more than the world's growing population (to provide adequate security even in the case of system shocks), managing land and water competition to ensure that more suitable agricultural land remains available for production, understanding ecosystem linkages (Walker et al., 2010), providing early warning and post-event recovery measures (Kramer et al., 2019; Nkiaka et al., 2019; Street et al., 2019); and understanding how system shocks could affect our ability to adapt. This is true for both short-term shocks resulting in acute impacts, as well as medium- to long-term chronic changes (Benton et al., 2018)

In general, under future socio-economic development and climate change, there are significant opportunities for improving the resilience of societies through integrated economic, governance as well as technical solutions as related to water and land system and their management. Starting with resilience of agricultural systems, given their role as the foundation of many economies, offers a sure bet when it comes to establishing broader, economy-wide resilient systems and populations.

\section{Climate adaptation and mitigation in agrarian based societies}

The impacts of climate change on agricultural productivity have the potential to be both positive and negative depending on crop and location. Evidence indicates that climate change has already reduced yields for some crops in some areas (Challinor et al., 2014; Lobell et al., 2011; Schlenker \& Roberts, 2009) and it is expected to slow growth in agricultural productivity in most crops and regions in the future (FAO, 2018; IPCC, 2014, 2019; G. Nelson et al., 2018; G. C. Nelson et al., 2014; Ruane et al., 2018; Wiebe et al., 2015, Rosegrant et al. 2017). These estimates are generally based on expected changes in mean temperature and precipitation (Box 1). Climate variability and extreme weather events are also expected to have important effects on productivity, but these effects are not yet well-incorporated in global economic models. In addition, the debate is not settled on whether $\mathrm{CO} 2$ concentration may have a fertilization effect on crop yields (Ainsworth \& Long, 2005; Ainsworth \& Ort, 2010; Asseng et al., 2019; Sharkey et al., 2007) even if such positive effects were to occur, climate change impacts on the nutrient content of food crops (G. Nelson et al., 2018) may nullify the CO2 fertilization effects, both globally and regionally (Beach et al., 2019). Studies also show that adoption of technologies and practices consistent

with a sustainable intensification approach such as heat and drought tolerant varieties, can reduce future climate change effects when adopted regionally (Islam et al., 2016; Robinson et al., 2016) and globally (M. W. Rosegrant et al., 2014), increasing yields and reducing resources use at the same time. 
Box 1 - Climate projections - current strengths and gaps

\begin{abstract}
In the near term (currently/now) we have good climate models that present a range of temperature and precipitation changes we expect to see at a global level. There are several resources offering consistent global quantitative data on estimated climate changes and associated impacts, including the IPCC reports, the IPCC Data Distribution Center, CMIP, and the ISIMIP database, while CORDEX concentrates on regional changes. Greater uncertainty exists at smaller geographical scales and for regional variation, nevertheless the understanding gained is still valuable in spite of the uncertainty.

From a temporal perspective there is significant evidence, again at the global scale, on trends over years and decades (particularly with respect to temperature). What is less well known and carries a high degree of uncertainty, are short term, intra- and inter-seasonal occurrences of changes to other climatic parameters, such as precipitation, wind speeds, cloud cover, and other factors that affect the timing, frequency and intensity of extreme events like floods and droughts. This is fundamental for planning for both society and environment to mitigate and adapt for change, nowhere more compelling than in less developed and developing countries where there is a strong and heavy reliance on natural resources and ecosystems to support livelihoods associated with agriculture and food systems.
\end{abstract}

The issue of resource use is key especially because impacts and the need to adapt to climate change are largely transmitted through changes in hydrologic systems. Nearly half of the world's population are already living in areas that are water scarce at least one month per year (Burek et. Al., 2016). On average, dry areas are becoming drier, wet areas wetter and water-related extremes such as floods, droughts, and storms become more frequent and intense. Future hydrologic variability will no longer look like the past, making planning more challenging. There is already a need for greater focus on populations vulnerable to water scarcity, lack of water services, and water-related extremes. Adaptation to climate change and assurance of food, water, energy, and environmental security will require intensifying that focus on reducing vulnerability to water-related extremes. Improvements will be required to water productivity, to integrated water resource planning, the management of distributed systems, to natural capital, to early warning systems, to monitoring networks, and equity.

For adaptation what is often lacking is monitoring to understand the impacts of climate changes and interventions and knowledge on options for a 1.5 degree target as well as less or more stringent climate targets. The arguments for adaptation are further complicated by the challenges in defining national and regional opportunities according to cultural, economic and biophysical settings. If we are going to understand what interventions will be most effective and how we can optimize systems with multiple interventions across sectors, we will need better and more consistent monitoring data to understand the resource balances.

Early warning and monitoring also applies to the threat from pests and diseases, which can have a devastating effect on agricultural production (Oerke, 2006; Strange \& Scott, 2005) and it is expected that climate change will further increase the frequency and severity of pest and disease outbreaks (BiberFreudenberger et al., 2016; Donatelli et al., 2017; Rosenzweig et al., 2001). The spread of pests and diseases, particularly under climate change, varies by region. Tonnang et al., (2015) suggest that in many parts of the world Tuta absoluta which attacks tomato plants can cause significant crop losses globally. 
However, the damage is regionally varied, with moderate increases associated with climate change where the pest already exists and in areas where the climate is more temperate, and larger increases where temperatures are already warmer. Tar spot complex disease in the US could decrease maize production: even at a one percent decrease in production, global effects will be felt in low-income countries which are heavily dependent on imports from the US, alongside losses to the maize industry locally (Mottaleb et al., 2019). Ex ante scenario analysis has also found that wheat blast in South Asia, particularly in areas of Bangladesh, India, and Pakistan could have devastating consequences and production losses pose a risk to food security in the region (Mottaleb et al., 2018). In general, shifts in cropping calendars, better weather forecast, adoption of different crops, and breeding for resistance to biotic stresses are all options to adapt to the potential increase in distribution of pests and diseases (De Pinto et. al., 2019).

Global action on adaptation requires an improved understanding of the opportunities and constraints for climate change adaptation at national and sub-regional geographies in developing countries. This requires an elaboration of risks (hazards, vulnerability, exposure) and related outcomes at the disaggregated level. This has recently been highlighted by the establishment of the Global Commission on Adaptation. The 2019 report (Global Commission on Adaptation, 2019) highlights three interconnected elements required: revolutions in understanding, planning, and financing. Only through these changes will it be possible to have a triple dividend of reduced losses, economic, social, and environmental benefits. The report suggests that significant net benefits may arise from policies and investments aimed at strengthening early warning systems, making new infrastructure resilient, improving dryland agriculture, protecting mangroves, and making water resource management more resilient.

While agriculture is significantly affected by climate change, it is also a major contributor to greenhouse gas emissions (Tongwane \& Moeletsi, 2018; Vermeulen et al., 2012), and is expected to become a proportionately larger contributor as efficiency gains are made in other sectors, including utilities and transportation. The production of some agricultural sectors appears to have smaller contribution to global emissions, but their relative contribution at the national scale can be much higher than global average. For example, GHG emissions from some crops in some regions are higher than from transport or industry sector. Thus, valid concerns have been voiced regarding the exacerbation of environmental degradation and climate change due to support measures that promote agricultural production with existing technologies (Mamun et al., 2019).

Mitigation options and opportunities for climate change are relatively well understood, particularly at the global level, although concerns have been raised about the tradeoffs between stringent global climate change mitigation measures and food security.

In moving towards a 'de-carbonised' world in which energy is increasingly provided by 'renewable' sources such as biofuels and hydro, it is necessary to better understand some of the trade-offs involved (Wu et. al., 2019). For example, Hasegawa et al., (2018) found that a carbon tax could decrease food security if it increases the cost of production, slows the expansion of agricultural land and increases demand for biofuels. This is not to say that mitigation measures are not essential, but rather that careful attention must be paid in their design to avoid unintended consequences. DePinto, (2020) shows that large-scale adoption of CSA (climate smart agriculture) can help break us loose from a trade-off between food security and emission abatement, thus creating potential win-win scenarios. Another important issue is the role of peatlands in storing carbon, the loss of which would release a significant amount of greenhouse gases (Silvius \& Schrier, 2018); (Leng et al., 2019). Furthermore, soil and land systems at landscape scale are 
increasingly threatened through drainage and drying caused by deforestation and expansion of agriculture (Roucoux et. al., 2017).

In relation to the response to climate change it would seem the arguments and possibilities for mitigation are better advanced than for adaptation. For mitigation, with declines in GHG emissions from energy and transport sectors the relative increase in the role of agriculture, forest and land use (AFOLU) as an emitter will come into stronger focus. Given the reliance of many developing regions on agriculture there is a potential for significant impact on this sector. Sapkota et al. (2019) analyzed this potential for India showing that, by 2030 , total emissions from agriculture may drop by $21 \%$ relative to the business as usual if technically feasible mitigation measures are adopted (e.g., improved water and nutrient management, restoration of degraded land, energy-efficient technologies, improved fertilizer production technologies). They also find that $80 \%$ of the total technical mitigation potential in Indian agriculture can be attained by adopting cost-beneficial mitigation options. Thus, the extent of adoption of various mitigation practices by farmers will be critical in achieving this mitigation potential. Likewise, Springmann, Clark, et al. (2018) analyzed the environmental impacts of increases in agricultural yields and changes in management practices (e.g., rebalancing of fertilizer application between over applying and under applying regions, increasing nitrogen-use efficiency and phosphorus recycling, improvements in water management, and agricultural mitigation options). They estimate that the environmental pressures of the food system fall by $3-30 \%$ relative to the 2050 baseline projection in medium-ambition scenarios, and by $11-54 \%$ in highambition scenarios if those measures were implemented.

\section{Improving land and water management}

In the future (2020-2030 and beyond to 2050), to improve land and water management, especially in developing countries, integrated approaches to agricultural, land and water management systems will be essential. Interventions that result in improvements in economic, governance and technical management are likely to have greater chance of being accepted, acted upon and owned where local to regional involvement has been incorporated. Furthermore, investments along with enabling policies need to focus and direct efforts towards sustainable use and management of land and water resources (Afriyanti et al., 2016; Hunter et al., 2017; Pastor et al., 2019).

A recent multi-model analysis (Stehfest et al., 2019) finds that the balance between changes in population and agricultural productivity will be critical in determining pressure for future extensification of crop and pasture land over the next several decades. They find that land use policy and changes in consumption patterns can play a key role in reducing risks associated with land use change and food insecurity. Of the many approaches to offset negative externalities associated with agricultural intensification and land use change, it is important to recognize the role of both intra- and inter-specific agrobiodiversity. Agrobiodiversity can help address trade-offs between meeting complex needs of farmers, producing more nutritious food, reducing the need for potentially harmful or scarce inputs such as fertilizer, pesticides, and water, and maintaining healthy ecosystems. A study by (Enahoro et al., 2019) shows that agrobiodiversity-based interventions can help mitigate key ecosystem service losses while increasing production of animal-source foods. The report shows that trade-offs emerge between meeting the demand for animal source foods and maintaining ecosystem services. Interventions based on increased 
crop productivity or more biodiverse systems, like agroforestry, show promise for mitigating losses to key ecosystem services. Moreover (Kozicka et al., 2019) show that increasing on-farm crop diversity can lead to higher socioeconomic system resilience, improve soil and human health, and provide higher incomes. Similarly, (Rosenstock et al., 2019) summarize the multiple avenues through which agroforestry interacts with planetary health, note the need for highly context-specific assessments and (Hughes et al., 2020) highlight the benefits of agroforestry for household asset accumulation while also pointing out the difficulties in achieving broad adoption.

Loss of forest, other tree cover, and wetland ecosystems as well as degradation of mountain ecosystems and water sheds represents a major global threat to biodiversity and the supply of ecosystem services such as habitat provisioning, clean water, soil conservation and protection (FAO, 2019, Powers and Jets, 2019)). Major immediate causes of forest and tree loss are logging and agricultural expansion, particularly those using fires (Busch and Ferretti-Galon, 2017, Purnomo et al., 2017; Vadrevu et al., 2019; Vijay et al., 2016). These are driven by a variety of mediating factors (such as price, technologies, infrastructure development) and underlying causes (such as policies, governance) (Armenteras et al., 2017; Austin et al., 2019; Gaveau et al., 2016; Jayathilake et al., 2020).

Investing in natural capital and specifically improved soil and water management is key to achieving sustainability in agricultural production, and ensure long-term food security and economic benefits, along with health and wellbeing (Rockström et al., 2017; CGIAR, 2015; CGIAR 2014). This means that agriculture landscapes need to be managed in a way that supports the multiple ecosystem services flowing to and from agriculture (i.e. supporting, regulating and cultural, not just provisioning services). Maintaining a variety of ecosystem services promotes resilience to shocks, including climate shocks. It is a key tenet of both sustainable intensification and climate-smart agriculture. However, some aspects of natural capital are still poorly or not monitored, even as they undergo rapid degradation and depletion. For the farmer and land manager such degradation is in effect loss of natural capital at the point of impact. Whilst downstream water bodies receiving and transporting these degradation products, negatively impact socio-ecological functioning.

Land and water degradation threaten food security of millions of people in the world, particularly for many of the poorest and most food insecure living in Asia, Africa and Latin America (Kaiser, 2004). Natural resource degradation leads to decreasing ecosystem resilience and provision of environmental services and contributes to persistent poverty (Costanza et al., 1997).

Soil and land degradation have been closely associated with poor agricultural practices since the dawn of agriculture (IPCC 2019). In the last twenty to thirty years knowledge of the causes and consequences of land degradation has been improving; the issue has been increasingly gaining attention after the 2008 food crisis (Kaiser 2004), because of a renewed look into the sources of vulnerability behind poverty and hunger (Nkonya et al, 2016).

Land degradation is often defined as a decline or loss in land productivity, ecological integrity (e.g., biodiversity and ecosystem functions), or value to humans, caused by direct or indirect human-induced processes, especially expansion of crop and grazing lands, unsustainable agricultural and forestry practices and including anthropogenic climate change (IPCC 2019; IPBES 2018). About a quarter of the icefree land masses and estimated to be degraded (IPCC 2019; Bai et al., 2015) leading to negative effects to the wellbeing of close to 3.2 billion people (Le et al., 2016), mostly living in developing countries. Land conversion and unsustainable land practices are estimated to have caused a $8 \%$ loss in global soil organic 
carbon (36 GigaTons of carbon) in the last two centuries; another $36 \mathrm{Gt} \mathrm{C}$ are projected to be lost from soil by 2050 if land management is not significantly improved (IPBES, 2018). This estimate includes losses due to encroachment of cropland into natural lands and degrading land practices, with most of the losses originating from sub-Saharan Africa (IPBES, 2018). Thus, land degradation is one of the most important contributors to climate change through the release of soil carbon and nitrous oxide into the atmosphere.

Land degradation and the ensuing loss of ecosystem services and land productivity seriously undermine the resilience of rural livelihoods to all shocks, from economic to bio-physical (e.g. biotic and abiotic stresses) including climate change. In all respects, degradation caused by unsustainable land management, most often motivated by the need for short-term gains, turns into long-term losses (Montanarella, 2018). As a result, avoidance of degradation from the start is a cost-effective strategy. Some regional studies have found that restoration, defined as "intentional activity that initiates or accelerates the recovery of an ecosystem from a degraded state" (IPBES, 2018), could provide benefits in terms of improved livelihoods that are ten times larger than the restoration costs (Montanarella, 2018). The extent and impacts of land degradation are such that meaningful improvements can be obtained only through a widespread effort. A global scenario analysis found that the inclusion of sustainable agricultural production in forest landscape restoration effortscan increase agricultural production, and food security by 2050, while also improve soil fertility and reduce greenhouse gas emissions on a global scale, with direct benefits to famers and to the global community (De Pinto et al., 2020).

Poor land management practices have also a direct bearing on degradation of water resources. Erosion affects water quality and causes sedimentation of reservoirs; overuse of fertilizers and pesticides causes pollution, thus reducing both water use and availability for society and ecosystem functioning, as well as impacting coastal systems and their valued economies. Equally even simple changes to land management practices such as changing agricultural tillage practice can lead to a reduction in soil erosion, surface runoff and increased yields (Abidela et al., 2019). Destruction and degradation of wetlands and buffer zones (such as mangroves) impacts the regulatory ecosystem service functions through for example, increased flood and drought risk as well as ability to buffer water quality. Broad-scale degradation of freshwater resource systems remains a critical sustainable development challenge. Threats to human water security may very well intensify throughout the coming century, especially across regions already in crisis, or those hosting a rising middle class.

As is the case for degraded land, costs to replace lost ecosystem services and degraded water resources is projected to grow several folds by mid-century, making immediate protection of water systems very cost effective. Proper watershed management practices have improved farm incomes and food security by about $50 \%$ and reduced the risk of crop failures from moisture stress by $30 \%$ (Gebregziabher et al., 2016). However, on one hand there is still a lack of technical expertise to support suitable interventions in local contexts, and advise on how they can be built up in a coordinated way; and on the other hand some of land and water interventions can represent large investments, and the benefits are still not fully understood (Adimassu et al., 2018).

Despite the large impacts that loss of ecosystem services have on the poor, investments in sustainable land and water management remain low (Nkonya et al, 2016). What is clear is that lack of action on land and water degradation is incompatible with building resilient and sustainable agro-ecosystems. Lack of 
action on sustainable land and watershed management is also incompatible with mitigation targets to limit global warming to $1.5^{\circ}$ or $2^{\circ} \mathrm{C}$.

Tackling land and water systems degradation challenges is one of the means to meet poverty alleviation and sustainability goals (Costanza et al., 1997). Despite the large impacts that loss of ecosystem services have on the poor, investments in sustainable land and water management remain low. What is clear is that lack of action on land and water degradation is incompatible with building resilient and sustainable agro-ecosystems. Lack of action on sustainable land and watershed management is also incompatible with mitigation targets to limit global warming to $1.5^{\circ}$ or $2^{\circ} \mathrm{C}$.

Good and efficient management of water systems requires first of all a good understanding of the current availability of water resources. This knowledge is already good at large scale, but it is better for surface waters compared to groundwaters. There is less agreement on current and future projections of water use and withdrawals, reflecting a lack of data in many regions of the world (Cuthbert et al., 2019; Satoh et al., 2017; Wada et al., 2013). Many of the world's river basins are either 'closed' or are 'closing', as water use within them exceeds or is approaching the amount of renewable water available (Molle et al., 2010). Similarly, there are extensive groundwater bodies in which extraction, largely for irrigation, is far in excess of the natural levels of replenishment. Water availability, while important, must also be considered alongside water quality. Agricultural intensification can lead to over-use of fertilizers which can lead to problems in water quality, such as eutrophication (Xie \& Ringler, 2017), and over-abstraction can lead to salinization (Javier Mateo-Sagasta, Sara Marjani Zadi, 2018) and improper management leading to soil degradation (Adimassu et al., 2017; Hussein et al., n.d.). At the same time many regions are experiencing the greater occurrence and intensity of extreme events, such as floods and droughts. These have direct impacts on society and ecosystems, as well as indirect negative impacts on livelihoods through our ability to produce food (Thornton et al. 2014).

Targeted investments to increase agricultural productivity sometimes treat water availability as given and thus fail to account for water-use and extraction. (Rosegrant et al., 2017) found investments in increasing productivity today can offset future increases in hunger due to climate change, but substantial reduction in hunger can also be achieved through investments that increase productivity while also targeting improved irrigation efficiency, and thus limiting groundwater extraction. However, investment costs increase significantly when these have to be done simultaneously. On the other hand, improving access to markets (e.g. through increased investment in infrastructure) may achieve similar food security goals, but at the expense of increased land conversion, and excessive water use - unless, again, R\&D and water use efficiency are also part of the mix (Rosegrant et al., 2017).

\section{Implications and Gaps}

Collectively the interface of climate change, societal development (economic growth and migration) with management of land and water systems creates extensive opportunities (and challenges) for meeting a range of SDG's (specifically $1,2,6,7$ ).

There is a need to accelerate our understanding of potential economic, governance and technical/biophysical interventions which will allow the transformation of agricultural, fisheries and 
aquaculture systems to meet the sustainability challenges faced by land and water ecosystems and the biodiversity they support. Within this context climate change mitigation and adaptation offer a significant opportunity.

As noted above, there are a range of economic models focusing on or including the agricultural sector at global and country scales that offer insights on interactions between socioeconomic drivers (such as changes in population, income and technology) and biophysical drivers (such as land and water resources and climate change). Socioeconomic drivers are expected to have larger effects than climate change on food demand and dietary change through mid-century (G. Nelson et al., 2018) . After mid-century, the impacts of climate change (under current projections) are expected to get worse, while demand-side pressures may ease as population growth slows and even reverses in many areas. Impacts of increasing climate variability remains an important gap.

Links between land and water systems, food systems, and energy also require further research. Efforts at the global level and some selected regional basins on understanding the interface of water, energy and food (a 'nexus' approach) and the ability to understand these dynamics and model them have been reviewed by (Johnson et al., 2019) (Byers et al., 2018) have piloted an approach combining a number of land, water, energy indicators with climate scenarios and income indicators to suggest the occurrence of 'hot-spots'.

Foresight methods have also been applied to improving understanding of the potential impacts of climate change on target populations such as poor livestock-keeping communities (Thornton, 2013). Such studies have informed the prioritization of agricultural and livestock research for development and may further have use for policy formulation in the poverty-land use-environment nexus. Points of entry for better management and transformation of land and water systems include economic policies (incentives, taxation), governance changes (local, national, regional), enhancing and building capacity: both technical and biophysical. These solutions need to be implemented with a strong emphasis on reducing vulnerability and with the idea of increasing resilience through both mitigation and adaptation to global change.

Underpinning many of these issues and needs are data and objective evidence. In the past the availability of data to drive our framing and understanding has been constrained by both capacity and technical means to collect data. However, over the recent past the acceleration of digital technologies are removing many of these constraints. For example, the use of remotely sensed data, the Internet of Things, Artificial and Machine Learning and social media generating and accessing multiple sources of data is almost at the stage of being overwhelming. What is now becoming a priority is how best to utilize these data and how they are collected and manages into supporting decisions and actions at multiple scales and in an inclusive manner (Wirths et. al., forthcoming and Ng et. al., 2021).

\section{Conclusion}

The text above provides a summary of some of the key pieces of evidence/citations that illustrate contemporary issues and imperatives to improve the management of land and water systems. The aim of this management is to assist society and the environment adapt and become more resilient in the light of a range of pressures created by society, principally, climate change, increasing population, increasing unequal wealth and migration. There is a raft of policies and frameworks to initiate the changes needed 
together with underpinning evidence. What is needed is to translate this into systematic solutions that can be readily implemented. In turn this requires further deepening of understanding across society, more integrated and systematic planning and financing. 


\section{References}

Abidela Hussein, M. et al. Deep Tillage Improves Degraded Soils in the (Sub) Humid Ethiopian Highlands. Land 8, (2019).

Adimassu, Z., Langan, S. \& Barron, J. Highlights of soil and water conservation investments in four regions of Ethiopia. (2018). Adimassu, Z.; Langan, S.; Barron, J. 2018. Colombo, Sri Lanka: International Water Management Institute (IWMI). 35p. (IWMI Working Paper 182). [doi: $10.5337 / 2018.214$

Adimassu, Z., Langan, S., Johnston, R., Mekuria, W., \& Amede, T. (2017). Impacts of Soil and Water Conservation Practices on Crop Yield, Run-off, Soil Loss and Nutrient Loss in Ethiopia: Review and Synthesis. Environmental Management, 59(1), 87-101. https://doi.org/10.1007/s00267-016-07761

Afriyanti, D., Kroeze, C., \& Saad, A. (2016). Indonesia palm oil production without deforestation and peat conversion by 2050. Science of the Total Environment, 557-558, 562-570. https://doi.org/10.1016/j.scitotenv.2016.03.032

Ainsworth, E. A., \& Long, S. P. (2005). What have we learned from 15 years of free-air $\mathrm{CO} 2$ enrichment (FACE)? A meta-analytic review of the responses of photosynthesis, canopy properties and plant production to rising CO2. New Phytologist, 165(2), 351-372. https://doi.org/10.1111/j.14698137.2004.01224.x

Ainsworth, E. A., \& Ort, D. R. (2010). How do we improve crop production in a warming world? Plant Physiology, 154(2), 526-530. https://doi.org/10.1104/pp.110.161349

Amarnath, et. al., (2019). Development of a system for drought monitoring and assessment in South Asia. Current Directions in Water Scarcity Research, Elsevier, Volume 2,P 133-163. ISBN 9780128148204, https://doi.org/10.1016/B978-0-12-814820-4.00010-9

Amarnath, G.; Amarasinghe, U.A.; Alahacoon, N. Disaster Risk Mapping (2021): A Desk Review of Global Best Practices and Evidence for South Asia. Sustainability, 13, 127 79. https://doi.org/10.3390/su132212779

Armenteras, D., Espelta, J. M., Rodríguez, N., \& Retana, J. (2017). Deforestation dynamics and drivers in different forest types in Latin America: Three decades of studies (1980-2010). Global Environmental Change, 46(September), 139-147. https://doi.org/10.1016/j.gloenvcha.2017.09.002

Asseng, S., Martre, P., Maiorano, A., Rötter, R. P., O'Leary, G. J., Fitzgerald, G. J., Girousse, C., Motzo, R., Giunta, F., Babar, M. A., Reynolds, M. P., Kheir, A. M. S., Thorburn, P. J., Waha, K., Ruane, A. C., Aggarwal, P. K., Ahmed, M., Balkovič, J., Basso, B., ... Ewert, F. (2019). Climate change impact and adaptation for wheat protein. Global Change Biology, 25(1), 155-173. https://doi.org/10.1111/gcb.14481

Austin, K. G., Schwantes, A., Gu, Y., \& Kasibhatla, P. S. (2019). What causes deforestation in Indonesia? Environmental Research Letters, 14(2), 024007. https://doi.org/10.1088/1748-9326/aaf6db.

Beach, R. H., Sulser, T. B., Crimmins, A., Cenacchi, N., Cole, J., Fukagawa, N. K., Mason-D’Croz, D., Myers, S., Sarofim, M. C., Smith, M., \& Ziska, L. H. (2019). Combining the effects of increased atmospheric carbon dioxide on protein, iron, and zinc availability and projected climate change on global diets: a modelling study. The Lancet Planetary Health, 3(7), e307-e317. https://doi.org/10.1016/S2542- 
5196(19)30094-4.

Benton, T. G., Bailey, R., Froggatt, A., King, R., Lee, B., \& Wellesley, L. (2018). Designing sustainable landuse in a $1.5^{\circ} \mathrm{C}$ world: the complexities of projecting multiple ecosystem services from land. Current Opinion in Environmental Sustainability, 31, 88-95. https://doi.org/10.1016/j.cosust.2018.01.011

Biber-Freudenberger, L., Ziemacki, J., Tonnang, H. E. Z., \& Borgemeister, C. (2016). Future risks of pest species under changing climatic conditions. PLOS ONE, 11(4), 1-17.

Bai, Z. et al. A longer, closer, look at land degradation. Agric. Dev. Special Is, 3-9. (2015). https://doi.org/10.1371/journal.pone.0153237

Burek P, Satoh Y, Fischer G, Kahil MT, Scherzer A, Tramberend S, Nava LF , Wada Y, et al. (2016). Water Futures and Solution - Fast Track Initiative (Final Report). IIASA Working Paper. IIASA, Laxenburg, Austria: WP-16-006

Busch, J., Ferretti-Gallon, K. 2017. What Drives Deforestation and What Stops It? A Meta-Analysis. Review of Environmental Economics and Policy, 11(1): 3-23.

Byers, E., Gidden, M., Leclère, D., Balkovic, J., Burek, P., Ebi, K., Greve, P., Grey, D., Havlik, P., Hillers, A., Johnson, N., Kahil, T., Krey, V., Langan, S., Nakicenovic, N., Novak, R., Obersteiner, M., Pachauri, S., Palazzo, A., ... Riahi, K. (2018). Global exposure and vulnerability to multi-sector development and climate change hotspots. Environmental Research Letters, 13(5), 055012.

https://doi.org/10.1088/1748-9326/aabf45

CGIAR Research Program on Water Land and Ecosystems. Ecosystem services and resilience framework. (2014).

CGIAR. CGIAR Strategy and Results Framework 2016-2030. Redefining how CGIAR does business until 2030. (2015).

Challinor, A. J., Watson, J., Lobell, D. B., Howden, S. M., Smith, D. R., \& Chhetri, N. (2014). A metaanalysis of crop yield under climate change and adaptation. Nature Climate Change, 4(4), 287-291. https://doi.org/10.1038/nclimate2153

Costanza et al., 1997. The value of the world's ecosystem services and natural capital. Nature 387, $253-$ 260.

Cuthbert, M. O., Taylor, R. G., Favreau, G., Todd, M. C., Shamsudduha, M., Villholth, K. G., MacDonald, A. M., Scanlon, B. R., Kotchoni, D. O. V., Vouillamoz, J. M., Lawson, F. M. A., Adjomayi, P. A., Kashaigili, J., Seddon, D., Sorensen, J. P. R., Ebrahim, G. Y., Owor, M., Nyenje, P. M., Nazoumou, Y., ... Kukuric, N. (2019). Observed controls on resilience of groundwater to climate variability in sub-Saharan Africa. Nature, 572(7768), 230-234. https://doi.org/10.1038/s41586-019-1441-7

DePinto, A. . N. C. ; H.-K. K. J. K. and S. D. (2020). Climate Smart Agriculture and Global Food-Crop Production. PloS One.

De Pinto, A. et al. (2019) The Role of Crop Production in the Forest Landscape Restoration ApproachAssessing the Potential Benefits of Meeting the Bonn Challenge. Front. Sustain. Food Syst. 4, 61 .

Donatelli, M., Magarey, R. D., Bregaglio, S., Willocquet, L., Whish, J. P. M., \& Savary, S. (2017). Modelling the impacts of pests and diseases on agricultural systems. Agricultural Systems. 
https://doi.org/10.1016/j.agsy.2017.01.019

Enahoro, D., Kozicka, M., Pfeifer, C., Jones, S., Tran, N., Chan, C. Y., Timothy, B., Gotor, E., \& Rich, K. M. (2019). Changing demand for animal source foods and their effects on the provision of ecosystem services. December, 1-4.

FAO. (2018). Climate change, agricultural trade and global food security.

FAO. (2019). The State of the World's Biodiversity for Food and Agriculture (J. Bélanger \& D. Pilling (eds.)). FAO Commission on Genetic Resources for Food and Agriculture Assessments.

Gaveau, D. L. A., Sheil, D., Husnayaen, Salim, M. A., Arjasakusuma, S., Ancrenaz, M., Pacheco, P., \& Meijaard, E. (2016). Rapid conversions and avoided deforestation: Examining four decades of industrial plantation expansion in Borneo. Scientific Reports, 6(September), 1-13. https://doi.org/10.1038/srep32017

Gebregziabher, G., Abera, D. A., Gebresamuel, G., Giordano, M. \& Langan, S. An assessment of integrated watershed management in Ethiopia. (2016).

Global Commission on Adaptation. (2019). Adapt Now: a Global Call for Leadership on Climate Resilience. https://cdn.gca.org/assets/2019-09/GlobalCommission_Report_FINAL.pdf

Hasegawa, T., Fujimori, S., Havlík, P., Valin, H., Bodirsky, B. L., Doelman, J. C., Fellmann, T., Kyle, P., Koopman, J. F. L., Lotze-Campen, H., Mason-D’Croz, D., Ochi, Y., Pérez Domínguez, I., Stehfest, E., Sulser, T. B., Tabeau, A., Takahashi, K., Takakura, J., van Meijl, H., ... Witzke, P. (2018). Risk of increased food insecurity under stringent global climate change mitigation policy. Nature Climate Change, 8(8), 699-703. https://doi.org/10.1038/s41558-018-0230-x

Hirvonen, K., Bai, Y., Headey, D., \& Masters, W. A. (2020). Affordability of the EAT-Lancet reference diet: a global analysis. The Lancet Global Health, 8(1), e59-e66. https://doi.org/10.1016/S2214109x(19)30447-4

Hughes, K., Morgan, S., Baylis, K., Oduol, J., Smith-Dumont, E., Vågen, T. G., \& Kegode, H. (2020). Assessing the downstream socioeconomic impacts of agroforestry in Kenya. World Development. https://doi.org/10.1016/j.worlddev.2019.104835

Hunter, M. C., Smith, R. G., Schipanski, M. E., Atwood, L. W., \& Mortensen, D. A. (2017). Agriculture in 2050: Recalibrating targets for sustainable intensification. BioScience, 67(4), 386-391. https://doi.org/10.1093/biosci/bix010

Hussein, M. A., Muche, H., Schmitter, P., Nakawuka, P., Tilahun, S. A., Langan, S., Barron, J., \& Steenhuis, T. S. (n.d.). Humid Ethiopian Highlands.

IPBES. Summary for policymakers of the assessment report on land degradation and restoration of the Intergovernmental Science- Policy Platform on Biodiversity and Ecosystem Services. (2018).

IPCC. (2014). Climate Change 2014 Synthesis Report (Vol. 218, Issue 2). https://doi.org/10.1016/S00220248(00)00575-3

IPCC. (2019). Global Warming of $1.5^{\circ} \mathrm{C}$. An IPCC Special Report on the impacts of global warming of $1.5^{\circ} \mathrm{C}$ above pre-industrial levels and related global greenhouse gas emission pathways, in the context of strengthening the global response to the threat of climate change,

IPCC. Climate Change and Land: an IPCC special report on climate change, desertification, land 
degradation, sustainable land management, food security, and greenhouse gas fluxes in terrestrial ecosystems. (2019).

Islam, A., Maitra, C., Pakrashi, D., \& Smyth, R. (2016). Microcredit Programme Participation and Household Food Security in Rural Bangladesh. Journal of Agricultural Economics, 67(2), 448-470. https://doi.org/10.1111/1477-9552.12151

Javier Mateo-Sagasta, Sara Marjani Zadi, H. T. (2018). A Global Review on Water Pollution from Agriculture.

Jayathilake, H. M., Prescott, G. W., Carrasco, L. R., Rao, M., \& Symes, W. S. (2020). Drivers of deforestation and degradation for 28 tropical conservation landscapes. Ambio. https://doi.org/10.1007/s13280-020-01325-9

Jiang, Y., Carrijo, D., Huang, S., Chen, J., Balaine, N., Zhang, W., van Groenigen, K. J., \& Linquist, B. (2019). Water management to mitigate the global warming potential of rice systems: A global metaanalysis. Field Crops Research, 234(November 2018), 47-54. https://doi.org/10.1016/j.fcr.2019.02.010

Johnson, N., Burek, P., Byers, E., Falchetta, G., Flörke, M., Fujimori, S., Havlik, P., Hejazi, M., Hunt, J., Krey, V., Langan, S., Nakicenovic, N., Palazzo, A., Popp, A., Riahi, K., van Dijk, M., van Vliet, M. T. H., van Vuuren, D. P., Wada, Y., ... Parkinson, S. (2019). Integrated solutions for thewater-energy-land nexus: Are global models rising to the challenge? Water (Switzerland), 11(11). https://doi.org/10.3390/w11112223

Karki, R., Hasson, S. ul, Gerlitz, L., Talchabhadel, R., Schenk, E., Schickhoff, U., Scholten, T., \& Böhner, J. (2018). WRF-based simulation of an extreme precipitation event over the Central Himalayas: Atmospheric mechanisms and their representation by microphysics parameterization schemes. Atmospheric Research, 214, 21-35. https://doi.org/10.1016/J.ATMOSRES.2018.07.016

Kaiser, J. 2004. Wounding earth's fragile skin. Science 304, 1616-1618

Kozicka, M., Groot, J. C. J., \& Gotor, E. (2019). Can crop diversity strengthen small-scale farmers' resilience? In Bioversity International (2019) Agrobiodiversity Index Report 2019: Risk and Resilience (pp. 135-144). Bioversity International. https://hdl.handle.net/10568/100820

Kramer, A. A., Sebat, F., \& Lissauer, M. (2019). A review of early warning systems for prompt detection of patients at risk for clinical decline. The Journal of Trauma and Acute Care Surgery, 87(1S Suppl 1), S67-S73. https://doi.org/10.1097/TA.0000000000002197

Le, Q. B., Nkonya, E. \& Mirzabaev, A. Biomass Productivity-Based Mapping of Global Land Degradation Hotspots. in Economics of Land Degradation and Improvement - A Global Assessment for Sustainable Development (eds. Nkonya, E., Mirzabaev, A. \& von Braun, J.) (Springer Open, 2016).

Leng, L. Y., Ahmed, O. H., \& Jalloh, M. B. (2019). Brief review on climate change and tropical peatlands. Geoscience Frontiers. https://doi.org/10.1016/j.gsf.2017.12.018

Lobell, D. B., Schlenker, W., \& Costa-Roberts, J. (2011). Climate trends and global crop production since 1980. Science, 333(6042), 616-620. https://doi.org/10.1126/science.1204531

Mamun, A., Martin, W., \& Tokgoz, S. (2019). Reforming Agricultural Subsidies for Improved Environmental Outcomes. December. https://www.foodandlandusecoalition.org/wpcontent/uploads/2019/08/Reforming-Agricultural-Subsidies-for-Improved-Environmental- 
Outcomes-2019_09_06-.pdf

Molle, F., Wester, P., \& Hirsch, P. (2010). River basin closure: Processes, implications and responses. Agricultural Water Management. https://doi.org/10.1016/j.agwat.2009.01.004

Montanarella, L., Scholes, R. \& Brainich, A. The IPBES Assessment Report on Land Degradation and Restoration. (Secretariat of the Intergovernmental Science-Policy Platform on Biodiversity and Ecosystem Services, 2018).

Mottaleb, K. A., Loladze, A., Sonder, K., Kruseman, G., \& San Vicente, F. (2019). Threats of Tar Spot Complex disease of maize in the United States of America and its global consequences. Mitigation and Adaptation Strategies for Global Change, 24(2), 281-300. https://doi.org/10.1007/s11027018-9812-1

Mottaleb, K. A., Rahut, D. B., Kruseman, G., \& Erenstein, O. (2018). Evolving food consumption patterns of rural and urban households in developing countries: A Bangladesh case. British Food Journal, 120(2), 392-408. https://doi.org/10.1108/BFJ-12-2016-0620

Mytton, O. T., Clarke, D., \& Rayner, M. (2012). Taxing unhealthy food and drinks to improve health. BMJ, 344, e2931

Nelson, G., Bogard, J., Lividini, K., Arsenault, J., Riley, M., Sulser, T. B., Mason-D’Croz, D., Power, B., Gustafson, D., Herrero, M., Wiebe, K., Cooper, K., Remans, R., \& Rosegrant, M. (2018). Income growth and climate change effects on global nutrition security to mid-century. Nature Sustainability, 1(12), 773-781. https://doi.org/10.1038/s41893-018-0192-z

Nelson, G. C., Valin, H., Sands, R. D., Havlík, P., Ahammad, H., Deryng, D., Elliott, J., Fujimori, S., Hasegawa, T., Heyhoe, E., Kyle, P., Von Lampe, M., Lotze-Campen, H., Mason d'Croz, D., van Meijl, H., van der Mensbrugghe, D., Müller, C., Popp, A., Robertson, R., ... Willenbockel, D. (2014). Climate change effects on agriculture: economic responses to biophysical shocks. Proceedings of the National Academy of Sciences of the United States of America, 111(9), 3274-3279. https://doi.org/10.1073/pnas.1222465110

Ng, Michelle; de Haan, Nicoline; King, Brian; Langan, Simon (2021) Promoting inclusivity and equity in information and communications technology for food, land, and water systems. Cali (Colombia): CGIAR Platform for Big Data in Agriculture. 67 p. https://cgspace.cgiar.org/handle/10568/115154

Nkiaka, E., Taylor, A., Dougill, A. J., Antwi-Agyei, P., Fournier, N., Bosire, E. N., Konte, O., Lawal, K. A., Mutai, B., Mwangi, E., Ticehurst, H., Toure, A., \& Warnaars, T. (2019). Identifying user needs for weather and climate services to enhance resilience to climate shocks in sub-Saharan Africa. Environmental Research Letters, 14(12). https://doi.org/10.1088/1748-9326/ab4dfe

Nkonya, E. et al. Global costs of land degradation. in Economics of Land Degradation and Improvement A Global Assessment for Sustainable Development (eds. Nkonya, E., Mirzabaev, A. \& von Braun, J.) (Springer Open, 2016).

Oerke, E. C. (2006). Crop losses to pests. Journal of Agricultural Science, 144(1), 31-43. https://doi.org/10.1017/S0021859605005708

Panyadee, P., Balslev, H., Wangpakapattanawong, P., \& Inta, A. (2018). Karen Homegardens: Characteristics, Functions, and Species Diversity. Economic Botany, 72(1), 1-19. https://doi.org/10.1007/s12231-018-9404-8 
Pastor, A. V., Palazzo, A., Havlik, P., Biemans, H., Wada, Y., Obersteiner, M., Kabat, P., \& Ludwig, F. (2019). The global nexus of food-trade-water sustaining environmental flows by 2050. Nature Sustainability, 2(6), 499-507. https://doi.org/10.1038/s41893-019-0287-1

Powers, R. P. and W. Jetz (2019). "Global habitat loss and extinction risk of terrestrial vertebrates under future land-use-change scenarios." Nature Climate Change 9(4): 323

Purnomo, H., Shantiko, B., Sitorus, S., Gunawan, H., Achdiawan, R., Kartodihardjo, H., \& Dewayani, A. A. (2017). Fire economy and actor network of forest and land fires in Indonesia. Forest Policy and Economics, 78, 21-31. https://doi.org/10.1016/J.FORPOL.2017.01.001

Rahman, T., Skupin, A., Falcke, M., \& Taylor, C. W. (2011). Rahman et al. reply. Nature, 478(7368). https://doi.org/10.1038/nature10494

Robinson, S., Mason-D'Croz, D., Sulser, T., Islam, S., Robertson, R., Zhu, T., Gueneau, A., Pitois, G., \& Rosegrant, M. W. (2016). The International Model for Policy Analysis of Agricultural Commodities and Trade (IMPACT): Model Description for Version 3. SSRN Electronic Journal. https://doi.org/10.2139/ssrn.2741234

Rockström, J., O. Gaffney, J. Rogelj, M. Meinshausen, N. Nakicenovic, and H.J. Schellnhuber. 2017. A roadmap for rapid decarbonization: Emissions inevitably approach zero with a "carbon law." Science 355: 1269-1271.

Rosegrant, M. W., Koo, J., Cenacchi, N., Ringler, C., Robertson, R., Fisher, M., Cox, C., Garret, K., Perez, N. D., \& Sabbagh, P. (2014). Food security in a world of natural resource scarcity: the role of agricultural technologies. International Food Policy Research Institute. https://doi.org/dx.doi.org/10.2499/9780896298477

Rosegrant, Mark W., Sulser, T. B., Mason-D'Croz, D., Cenacchi, N., Nin-Pratt, A., Dunston, S., Zhu, T., Ringler, C., Wiebe, K. D., Robinson, S., Willenbockel, D., Xie, H., Kwon, H.-Y., Johnson, T., Thomas, T. S., Wimmer, F., Schaldach, R., Nelson, G. C., \& Willaarts, B. (2017). Quantitative foresight modeling to inform the CGIAR research portfolio. April, 225.

http://ebrary.ifpri.org/cdm/singleitem/collection/p15738coll2/id/131144

Rosenstock, T. S., Dawson, I. K., Aynekulu, E., Chomba, S., Degrande, A., Fornace, K., Jamnadass, R., Kimaro, A., Kindt, R., Lamanna, C., Malesu, M., Mausch, K., McMullin, S., Murage, P., Namoi, N., Njenga, M., Nyoka, I., Paez Valencia, A. M., Sola, P., ... Steward, P. (2019). A Planetary Health Perspective on Agroforestry in Sub-Saharan Africa. One Earth, 1(3), 330-344. https://doi.org/10.1016/j.oneear.2019.10.017

Rosenzweig, C., Iglesias, A., Yang, X. B., Epstein, P., \& Chivian, E. (2001). Climate Change and Extreme Weather Events; Implications for Food Production, Plant Diseases, and Pests. Global Change and Human Health, 2(2), 90-104. https://doi.org/10.1023/A:1015086831467

Roucoux, K., Lawson, I., Baker, T., Del Castillo Torres, D., Draper, F., Lähteenoja, O., Gilmore, M., Honorio Coronado, E., Kelly, T., Mitchard, E. and Vriesendorp, C. (2017), Threats to intact tropical peatlands and opportunities for their conservation. Conservation Biology, 31: 1283-1292. https://doi.org/10.1111/cobi.12925

Ruane, A. C., Phillips, M. M., \& Rosenzweig, C. (2018). Climate shifts within major agricultural seasons for +1.5 and $+2.0^{\circ} \mathrm{C}$ worlds: HAPPI projections and AgMIP modeling scenarios. Agricultural and Forest Meteorology, 259, 329-344. https://doi.org/10.1016/j.agrformet.2018.05.013 
Satoh, Y., Kahil, T., Byers, E., Burek, P., Fischer, G., Tramberend, S., Greve, P., Flörke, M., Eisner, S., Hanasaki, N., Magnuszewski, P., Nava, L. F., Cosgrove, W., Langan, S., \& Wada, Y. (2017). Multimodel and multi-scenario assessments of Asian water futures: The Water Futures and Solutions (WFaS) initiative. Earth's Future, 5(7), 823-852. https://doi.org/10.1002/2016EF000503

Sapkota, T. B., Vetter, S. H., Jat, M. L., Sirohi, S., Shirsath, P. B., Singh, R., ... \& Stirling, C. M. (2019). Costeffective opportunities for climate change mitigation in Indian agriculture. Science of the Total Environment, 655, 1342-1354.

Schlenker, W., \& Roberts, M. J. (2009). Nonlinear temperature effects indicate severe damages to U.S. crop yields under climate change. Proceedings of the National Academy of Sciences, 106(37), 15594-15598. https://doi.org/10.1073/PNAS.0906865106

Sharkey, T. D., Bernacchi, C. J., Farquhar, G. D., \& Singsaas, E. L. (2007). Fitting photosynthetic carbon dioxide response curves for C3 leaves. Plant, Cell and Environment, 30(9), 1035-1040. https://doi.org/10.1111/j.1365-3040.2007.01710.x

Sharma, A., Hamlet, A. F., Fernando, H. J. S., Catlett, C. E., Horton, D. E., Kotamarthi, V. R., Kristovich, D. A. R., Packman, A. I., Tank, J. L., \& Wuebbles, D. J. (2018). The Need for an Integrated Land-LakeAtmosphere Modeling System, Exemplified by North America's Great Lakes Region. Earth's Future, 6(10), 1366-1379. https://doi.org/10.1029/2018EF000870

Silvius, M., \& Schrier, A. (2018). Climate regulation: Southeast asian peat swamps. In The Wetland Book: I: Structure and Function, Management, and Methods (pp. 1197-1204). Springer Netherlands. https://doi.org/10.1007/978-90-481-9659-3_237

Springmann, M., Clark, M., Mason-D'Croz, D., Wiebe, K., Bodirsky, B. L., Lassaletta, L., de Vries, W., Vermeulen, S. J., Herrero, M., Carlson, K. M., Jonell, M., Troell, M., DeClerck, F., Gordon, L. J., Zurayk, R., Scarborough, P., Rayner, M., Loken, B., Fanzo, J., ... Willett, W. (2018). Options for keeping the food system within environmental limits. Nature, 562(7728), 519-525. https://doi.org/10.1038/s41586-018-0594-0

Springmann, M., Sacks, G., Ananthapavan, J., \& Scarborough, P. (2018). Carbon pricing of food in Australia: an analysis of the health, environmental and public finance impacts. Australian and New Zealand Journal of Public Health, 42(6), 523-529. https://doi.org/10.1111/1753-6405.12830

Springmann, M., Wiebe, K., Mason-D'Croz, D., Sulser, T. B., Rayner, M., \& Scarborough, P. (2018). Health and nutritional aspects of sustainable diet strategies and their association with environmental impacts: a global modelling analysis with country-level detail. The Lancet Planetary Health, 2(10), e451-e461. https://doi.org/10.1016/S2542-5196(18)30206-7

Stehfest, E., van Zeist, W. J., Valin, H., Havlik, P., Popp, A., Kyle, P., Tabeau, A., Mason-D'Croz, D., Hasegawa, T., Bodirsky, B. L., Calvin, K., Doelman, J. C., Fujimori, S., Humpenöder, F., LotzeCampen, H., van Meijl, H., \& Wiebe, K. (2019). Key determinants of global land-use projections. Nature Communications, 10(1). https://doi.org/10.1038/s41467-019-09945-w

Strange, R. N., \& Scott, P. R. (2005). Plant Disease: A Threat to Global Food Security. Annual Review of Phytopathology, 43(1), 83-116. https://doi.org/10.1146/annurev.phyto.43.113004.133839

Street, R. B., Pringle, P., Lourenço, T. C., \& Nicolletti, M. (2019). Transferability of decision-support tools. Climatic Change, 153(4), 523-538. https://doi.org/10.1007/s10584-018-2263-6

Thornton, P. K. ;Va. de S. J. . N. A. . H. M. (2013). Climate change: do we know how it will affect 
smallholder livestock farmers? In The Futures of Agriculture (Vol. 43, Issues 1-2). https://doi.org/10.1017/S088918930000549X

Thornton, Philip K, Polly J Ericksen, Mario Herrero, and Andrew J Challinor. "Climate Variability and Vulnerability to Climate Change: A Review." Global Change Biology 20, no. 11 (2014): 3313-28. https://doi.org/10.1111/gcb.12581

Tongwane, M. I., \& Moeletsi, M. E. (2018). A review of greenhouse gas emissions from the agriculture sector in Africa. In Agricultural Systems. https://doi.org/10.1016/j.agsy.2018.08.011

Tonnang, H. E. Z., Mohamed, S. F., Khamis, F., \& Ekesi, S. (2015). Identification and risk assessment for worldwide invasion and spread of tuta absoluta with a focus on Sub-Saharan Africa: Implications for phytosanitary measures and management. PLOS ONE, 10(8), 138319. https://doi.org/10.1371/journal.pone.0135283

Vadrevu, K. P., Lasko, K., Giglio, L., Schroeder, W., Biswas, S., \& Justice, C. (2019). Trends in Vegetation fires in South and Southeast Asian Countries. Scientific Reports, 9(1), 1-13. https://doi.org/10.1038/s41598-019-43940-x

Vermeulen, S. J., Aggarwal, P. K., Ainslie, A., Angelone, C., Campbell, B. M., Challinor, A. J., Hansen, J. W., Ingram, J. S. I., Jarvis, A., Kristjanson, P., Lau, C., Nelson, G. C., Thornton, P. K., \& Wollenberg, E. (2012). Options for support to agriculture and food security under climate change. Environmental Science and Policy, 15(1), 136-144. https://doi.org/10.1016/j.envsci.2011.09.003

Vijay, V., Pimm, S. L., Jenkins, C. N., \& Smith, S. J. (2016). The Impacts of Oil Palm on Recent Deforestation and Biodiversity Loss. PloS One, 11(7), e0159668. https://doi.org/10.1371/journal.pone.0159668

Wada, Y., Wisser, D., Eisner, S., Flörke, M., Gerten, D., Haddeland, I., Hanasaki, N., Masaki, Y., Portmann, F. T., Stacke, T., Tessler, Z., \& Schewe, J. (2013). Multimodel projections and uncertainties of irrigation water demand under climate change. Geophysical Research Letters, 40(17), 4626-4632. https://doi.org/10.1002/grl.50686

Wada, Y., Gleeson, T. \& Esnault, L. Wedge approach to water stress. Nature Geosci 7, 615-617 (2014). https://doi.org/10.1038/ngeo2241

Walker, B., Pearson, L., Harris, M., Maler, K. G., Li, C. Z., Biggs, R., \& Baynes, T. (2010). Incorporating resilience in the assessment of inclusive wealth: An example from South East Australia. Environmental and Resource Economics, 45(2), 183-202. https://doi.org/10.1007/s10640-0099311-7

Wiebe, K., Lotze-Campen, H., Sands, R., Tabeau, A., Van Der Mensbrugghe, D., Biewald, A., Bodirsky, B., Islam, S., Kavallari, A., Mason-D'Croz, D., Müller, C., Popp, A., Robertson, R., Robinson, S., Van Meijl, H., \& Willenbockel, D. (2015). Climate change impacts on agriculture in 2050 under a range of plausible socioeconomic and emissions scenarios. Environmental Research Letters, 10(8). https://doi.org/10.1088/1748-9326/10/8/085010

Willett, W., Rockström, J., Loken, B., Springmann, M., Lang, T., Vermeulen, S., Garnett, T., Tilman, D., DeClerck, F., Wood, A., Jonell, M., Clark, M., Gordon, L. J., Fanzo, J., Hawkes, C., Zurayk, R., Rivera, J. A., De Vries, W., Majele Sibanda, L., ... Murray, C. J. L. (2019). Food in the Anthropocene: the EAT-Lancet Commission on healthy diets from sustainable food systems. The Lancet, 393(10170), 447-492. https://doi.org/10.1016/S0140-6736(18)31788-4 
Wirths, J., Winowiecki, L., Estrada Carmona, N., Greatrix, E., Langan, S.J., Uhlenbrook, S., Ringler C. ( 2022). Sharing research data in a connected world for connected decisions: lessons learned from the CGIAR Research Program on Water, Land and Ecosystems (WLE), CGIAR Repor

Wu, W. C., Hasegawa, T., Ohashi, H., Hanasaki, N., Liu, J. Y., Matsui, T., Fujimori, S., Masui, T., Takahashi, K. (2019). "Global advanced bioenergy potential under environmental protection policies and societal transformation measures." Global Change Biology Bioenergy 11(9): 1041-1055.

Xie, H., \& Ringler, C. (2017). Agricultural nutrient loadings to the freshwater environment: The role of climate change and socioeconomic change. Environmental Research Letters, 12(10).

https://doi.org/10.1088/1748-9326/aa8148 